\title{
American Pediatric Society 2014 presidential address: the thrill of discovery (and other foundations of biomedical research)
}

\author{
Alan L. Schwartz'
}

U nited States federal research funding has been on a downward trend for the past decade. The thirty billion dollar National Institutes of Health (NIH) budget is about 25\% less in purchasing power today than it was a decade ago. What does this mean for our next generation?

The belief that biomedical research pays a generous return on investment is well-grounded, not only in dollars, but in lives saved and illnesses mitigated. Nowhere is this more dramatic than in pediatrics. Witness the efficacy of vaccines in Table 1.

A person born in the United States today will live about 30 years longer than one born a century ago. Whenever one hears about a biomedical research breakthrough in the United States, it is likely that National Institutes of Health (NIH) and/ or other federal research dollars supported it. Yet, not alone. The academic medical centers are the fulcrum for those federal research dollars. Innovation at our academic medical centers is one of the most critical cornerstones of American medicine. "For decades, innovation has been fueled by federally funded research that is conducted at universities across our nation." says University of Wisconsin Chancellor, Rebecca Blank; "America's future economic prosperity depends on increased investments in research and education that will accelerate innovation and inspire future generations of scientists."

The field of biomedicine has never been more dynamic; the opportunities ahead nearly unlimited. Yet, academic medicine is under serious threat. The United States spent about $18 \%$ of its gross national product on healthcare last year. Universities' Schools of Medicine, and their associated teaching hospitals, accounted for about $20 \%$ of these costs. Thus, in the United States, the foundation for biomedical discovery research is anchored within our research universities.

The first American university to emphasize research rather than undergraduate teaching was Johns Hopkins, established in 1876. Hopkins, who donated seven million dollars to build a new hospital and new type of university, had made his fortune in real estate, banking, and railroads. Among the intellectual leaders of this new university was Daniel Coit Gilman who became the university's first president and revolutionized the idea of the American university. For Gilman, it was essential that the faculty have the freedom to conduct research. One of its earliest students was Thomas Hunt Morgan who we will discuss below. At Gilman's retirement celebration, Woodrow Wilson, who earned his $\mathrm{PhD}$ at Hopkins in 1886, said, "In this, your greatest achievement, you established in America a new and higher university ideal whose essential feature was...the education of trained and vigorous minds through the search for truth under the guidance and with the cooperation of master investigators."

The history of "The Great American University, its rise to preeminence, its indispensable national role and why it must be protected" has been beautifully described by Jonathan R. Cole, former Provost of Columbia University (1).

Johns Hopkins set the standard with a focus on the creation of new knowledge via research. By 1900, discovery research, as well as teaching, began to be embraced by older, private, American universities, including Harvard, Columbia, the University of Chicago, Cornell, Stanford, as well as several public institutions, such as the Universities of Michigan and Wisconsin.

In 1892, John D. Rockefeller established the University of Chicago led by William Rainey Harper. Harper entered college at 10 years of age, received his bachelor's degree at 14 and a $\mathrm{PhD}$ at 18 . He was a master of setting high standards, recruiting top faculty talent, and charting the course of excellence at the new University of Chicago.

In 1901, Rockefeller founded the Rockefeller Institute of Medical Research, now Rockefeller University; the first institution in the United States devoted solely to biomedical research and focused on understanding the underlying causes of disease. Simon Flexner, a Johns Hopkins trained pathologist, was Rockefeller's first director. The Rockefeller Institute Hospital opened in 1910 and was the first center for clinical research in the United States. Oswald T. Avery came to Rockefeller in 1913, and with Colin MacLeod and Maclyn McCarty in 1944, discovered DNA as the substance that transmits hereditary information (arguably one of the most important discoveries not awarded a Nobel Prize).

Throughout the second half of the 19th century, several other universities vacillated between strong commitments to research and discovery, and to teaching. One fascinating example is that of Yale. In 1854, the Yale Scientific School was created and soon became the Sheffield Scientific School. These

Presented at: The 2014 Annual Meeting of the American Pediatric Society, Vancouver, British Columbia, Canada.

'Department of Pediatrics, Washington University School of Medicine, St Louis, Missouri. Correspondence: Alan L. Schwartz (schwartz@wustl.edu)

Received 15 May 2014; accepted 19 May 2014; advance online publication 9 July 2014. doi:10.1038/pr.2014.81 
science students at Yale tended to be separate and nonequal. They completed their degree in three, not the usual 4 years, yet, had lower admission standards. Further, they were "not permitted to sit with regular academic students in chapel." Despite this challenging start, "science schools", which ultimately grew into Science Departments, became a central part of the development of the research intensive universities.

At the beginning of the 20th century, universities began to widen their view beyond the liberal arts, law, medicine, and science. These full-service universities were criticized by none other than Abraham Flexner, Simon Flexner's brother, who, in 1910, evaluated the state of medical education in the United States and Canada. By the 1930's, Flexner, who admired the focus at John Hopkins, was seriously concerned that American universities were insufficiently focused on the pursuit of new knowledge; that is, discovery.

By 1940, most of the key ingredients for the making of the great American research universities were in place. As Cole notes, among these was the slow, but steady, movement from elitism to inclusion, where the doors of research intensive universities now began to open to the talented among ethnic and religious groups, as well as to women. At the same time, America's research intensive universities began to establish what were to become their shared core values, including organized skepticism, creation of new knowledge, free and open communication of ideas, the peer-review system, and intellectual progeny.

For one sterling example of the fertility of the research intensive universities, let us look to Thomas Hunt Morgan. Morgan received his $\mathrm{PhD}$ in developmental biology at Johns Hopkins in 1890. He joined the Columbia University faculty, in 1904, where he began his studies of Drosophila biology, establishing his famous Fly Room. Among his many seminal discoveries, Morgan, in 1910, demonstrated the role of chromosomes in heredity, for which, in 1933, he received the Nobel Prize.

Throughout the 1930's and 40's, America's research universities expanded rapidly. It was the era of the birth of big science, led by physicists and chemists in part for the war effort. Among the key drivers of this effort was Vannevar Bush,

Table 1. Vaccine efficacy

\begin{tabular}{lccc}
\hline Disease & $\begin{array}{c}\text { 20th Century } \\
\text { annual } \\
\text { morbidity }\end{array}$ & $\begin{array}{c}2010 \\
\text { Reported } \\
\text { cases }\end{array}$ & $\begin{array}{c}\% \\
\text { Decrease }\end{array}$ \\
\hline Smallpox & 29,005 & 0 & $100 \%$ \\
Diphtheria & 21,053 & 0 & $100 \%$ \\
Pertussis & 200,752 & 21,291 & $89 \%$ \\
Tetanus & 580 & 8 & $99 \%$ \\
Polio & 16,316 & 0 & $100 \%$ \\
Measles & 530,217 & 61 & $>99 \%$ \\
Mumps & 162,344 & 2,528 & $98 \%$ \\
Rubella & 47,745 & 6 & $>99 \%$ \\
Hemophilus influenza & $\sim 20,000$ & 16 & $>99 \%$ \\
type b $(<5$ y old) & & & \\
\hline
\end{tabular}

Data obtained from http://www.cdc.gov/vaccines.
Vice President of Massachusetts Institute of Technology. Bush convinced President Roosevelt to create the National Defense Research Committee, which evolved into the Office of Scientific Research. Bush chaired the office and developed the blueprint for both the organization and the funding of US research following World War II. Bush's document, presented to the President in July 1945, was entitled "Science - The Endless Frontier" (2). Among the key questions Bush asked was, "How could medical research be encouraged?" He envisioned two types of science-basic and applied or "curiosity-driven" and "mission-driven." Then, as now, one difficulty is apparent-can one fit medical or biological science neatly into one of these categories. The efforts to develop therapies, and ultimately to seek cures to diseases, invariably crosses the boundaries between the two.

James B. Conant, Harvard's President, summed up Bush's innovative call for resources: "The essence of the revolution was the shift from expanding research in government laboratories to the use of federal money to support work in universities and scientific institutes."

While the NIH, in fact, began in 1887 as a one-room laboratory of the Marine Service Hospital; in 1930, the Randall Act changed its mission and renamed it as the National Institute of Health. Following World War II, the scale and scope of the NIH dramatically expanded and extramural research grant support began. In 1947, the new grants program awarded four million dollars. The major growth of NIH, from 1955 to 1968, under its exceptional director, James Shannon, has been referred to as its "golden years." Grant awards exceeded one billion dollars per year by 1970, ten billion dollars in 1993, and thirty billion dollars in 2009 (Figure 1).

The 1960's saw another major innovation in America's universities led by Clark Kerr, with his development of what he termed the "multiversity." He described this in his 1963 Godkin lectures at Harvard, "The Uses of the University." The multiversity is a system initially created in California with different schools, colleges, and universities integrated to fulfill a variety of missions. The pinnacle of this system was the major research universities, including University of California, Berkeley, University of

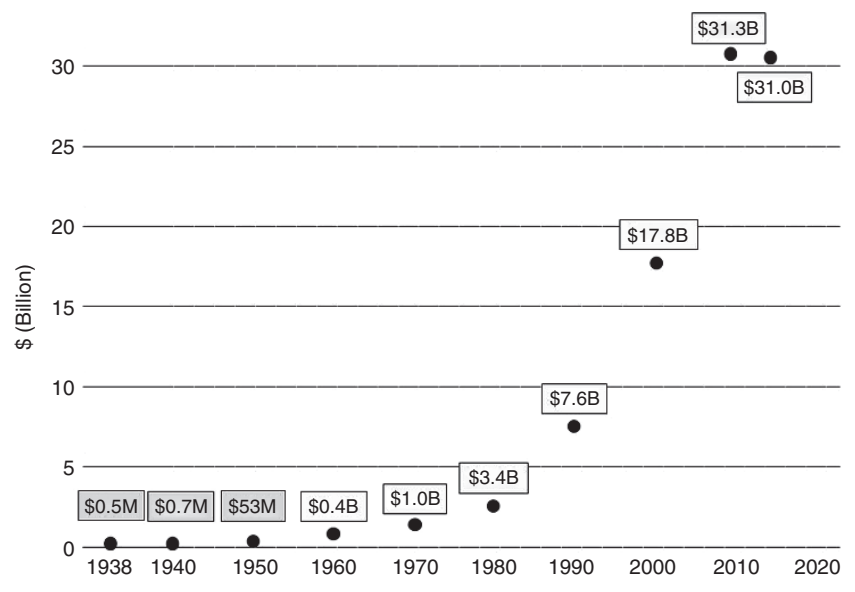

Figure 1. National Institutes of Health funding. 
California, Los Angeles, University of California, San Francisco, and thereafter, University of California, San Diego. Kerr's vision was that America's economic welfare was critically dependent upon its ability to develop a highly educated population, as well as, an elite group of scientists who would produce ideas of substantial social value. This was certainly the case for half a century. Upon Kerr's death in 2003, sociologist, Martin Trow, said that "history will simply know him as the most distinguished university president of the $20^{\text {th }}$ century."

In Kerr's final 1963 Godkin lecture, "The Future of the City of Intellect," he emphasized that "the fastest growing intellectual field today is biology. Here there is a veritable revolution." "If the first half of the $20^{\text {th }}$ century may be said to have belonged to the physical sciences, the second half may well belong to the biological." And so it has.

The 1970s, 80s, and 90s witnessed an explosive growth of American medical schools, being reshaped into huge researchoriented enterprises. Many became "health science" centers. Schools of Medicine, and their component departments, expanded dramatically in faculty size, research activity, and societal impact. The rapid and continuing advances, in scientific knowledge, new technologies, and health-related research, produced substantive changes in the Universities. At many, including my own, the School of Medicine became the largest, and often the most distinguished, School within the University.

Let us pause for a moment...

Close your eyes...

Think of an example of a research university opening its doors to a nascent young talent, providing the opportunity to explore and to experience the thrill of discovery.

I have many examples. Today, it is Arthur Kornberg, a remarkable physician-scientist and biochemist. His discovery, of the enzyme DNA polymerase and how it assembles DNA, earned him the Nobel Prize. Kornberg died, in 2007, at 89 (Figure 2). He had worked in his laboratory, at Stanford, up until a few days before his death. In 2006, his son, Roger, was the Nobel laureate in Chemistry for his work on RNA polymerase. Arthur Kornberg, arguably one of the most important

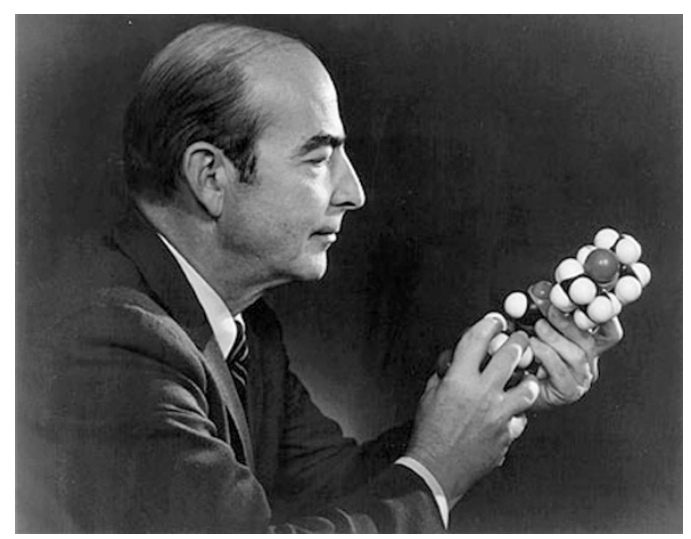

Figure 2. Arthur Kornberg, MD, Nobel Laureate. Reprinted with permission from the Stanford University Archives, Stanford, CA. physician-scientists of our time, described his successive research problems, and the challenges they presented, in his treatise "For the Love of Enzymes" (3).

Kornberg chose medicine, because he was an avid student and, because in 1937, medical school provided an escape from the depths of the Great Depression. His parents had immigrated from Eastern Europe in early 1900. His father was a sewing machine operator in the Lower East Side of New York. Asked years later, by a biochemistry mentor, what did he collect as a child-butterflies, beetles? Kornberg replied, "matchbooks"-it was the flora and fauna of his Brooklyn streets and subways. After high school, and a New York State Regents Scholarship, Kornberg entered City College of New York and thereafter, the University of Rochester School of Medicine. While he enjoyed studying medicine, he described biochemistry as "rather dull"-a description of constituents of blood, tissue, and urine-the dynamism of macromolecules and energy metabolism was not yet known.

As a medical student, he noted a persistent mild yellow jaundice to the whites of his eyes. His bilirubin was well above normal levels. With an intolerance for fatty food, he was advised to have his gall bladder removed. To avoid it, he discovered seven other medical students with mild jaundice and elevated bilirubin like his. He then evaluated patients recovering from infectious hepatitis and assorted controls. His results, published as his first paper, "Latent Liver Disease in Persons Recovered from Catarrhal Jaundice and in Otherwise Normal Medical Students as Revealed by the Bilirubin Excretion Test" appeared during his internal medicine internship in the 1942 Journal of Clinical Investigation. This was the rediscovery of Gilbert's disease (4), originally described in the French literature in 1901. More importantly, this paper was read by the Army and Navy Medical Corps and by Rolla Dyer, Director of the NIH, all of whom contacted Kornberg as they were dealing with large numbers of World War II recruits who developed jaundice upon vaccination. Kornberg was given offers to join the tiny upstart NIH, and the US Public Health Service, to begin his "training" in science. His first project (1944-1945) focused on nutritional constituents and cofactors.

After the War's end, uninspired by his nutrition studies, he requested to spend a year learning biochemistry-he wanted to study enzymes and the source of adenosine triphosphate. While enzymes were known from the late 19th century's studies of fermentation, their high catalytic potency was only just then being explored. NIH supported Kornberg to spend 18 months in two different enzymology laboratories-the first, via real serendipity, was a referral to work with a young, Spanish scientist who had escaped persecution in Europe and was given a bench at New York University in 1945. Severo Ochoa had just discovered that pigeon brain produced three molecules of adenosine triphosphate for each atom of oxygen consumed. Kornberg became Ochoa's first trainee. Ochoa, it turns out, had studied earlier in Heidelberg with Meyerhoff, at Oxford with Peters, and at Washington University with Carl Cori. We will come back to Ochoa later. 
On his first day in the laboratory, Kornberg was presented with six fresh pig hearts and charged with purifying the enzyme, aconitase. With Ochoa, Kornberg learned the "philosophy and practice of enzyme purification"-the basis of his life's work. Purification allows one to remove contaminants and get at the true essence of an enzyme's action, its function, and ultimately, its structure. It allows one to reconstitute nature in a test-tube. Over his lifetime, Kornberg purified and elegantly studied over 30 enzymes-one of which we will look at in a moment. He often said, "I never met a dull enzyme."

After a year with Ochoa, Kornberg, in January 1947, came to St. Louis to study with Ochoa's mentor, Carl Cori. Cori and his wife, Gerty, had come to Washington University School of Medicine in 1931; he as Professor of Pharmacology. The Cori's had the wisdom to extend physiological studies, in animals and tissues, to crude cell extracts and ultimately, to purified enzymes. Kornberg would study the enzymatic origin of inorganic pyrophosphate, a high energy metabolite in cellular energy generation. While the experiments were exciting, Kornberg was disappointed not to find the soluble enzyme of adenosine triphosphate generation. It became clear, years later, that adenosine triphosphate was generated via the enzyme chain embedded in the insoluble mitochondria. Yet, Kornberg learned enzymology and the scientific method. One month after Kornberg returned, from the Cori laboratory, to the NIH, Carl and Gerty Cori were awarded the Nobel Prize for their pioneering studies of glycogen metabolism and its enzymology.

Back at the NIH, Kornberg set up his own laboratory and began studies on nucleotide pyrophosphatase.

Then in 1952, Washington University School of Medicine called and asked Kornberg to Head the new Department of Microbiology. In January 1953, Kornberg moved to St. Louis. Here, Kornberg established, arguably, the world's most exciting microbiology department. His recruits included Paul Berg, David Hogness, Robert Lehman, and Dale Kaiser. Equally important, Kornberg redirected his own work to the synthesis of DNA. As studying carbohydrate breakdown provided insights into its synthesis, Kornberg hoped that studying DNA breakdown would provide insights into its synthesis. A second insight was to pick a model system-he selected Escherichia coli, the gut bacterium. In one classic Kornberg experiment, he convinced the Grain Processing Corporation of Muscatine, Iowa, to use their 10,000 gallon vat to produce $200 \mathrm{lbs}$. of bacteria from which he isolated $500 \mathrm{mgs}$ of pure DNA polymerase - a 200,000-fold purification - and that was in 1956! Five classic papers, in 1957-1958, on the enzymatic synthesis of DNA resulted, as well as a detailed understanding of how DNA replicates itself.

In 1959, Kornberg was recruited to Stanford to serve as Chairman and establish a new Department of Biochemistry. For the past 50 years, it was likely the finest Department of Biochemistry in the world.

That same year, October 1959, was also a landmark occasion for Kornberg-he was awarded the Nobel Prize in Medicine for his discovery of DNA polymerase and the mechanisms of DNA and RNA synthesis-work done at Washington University the previous 4 years. Significantly, he shared the Prize with Severo Ochoa, his mentor at New York University in 1946.

Kornberg went on to study dozens of enzymes of nucleic acid biology. Purification was always step one. "Don't waste clean thoughts on dirty enzymes" is one of his landmark phrases.

Stanford University owes much to Arthur Kornberg. It was he, perhaps more than anyone else, who put Stanford on the map in the medical and biological sciences, creating an environment that had a huge impact on all of biology, an impact that went far beyond that of the work from his own laboratory. He was an impassioned scientist, teacher, mentor, and colleague. He wrote eloquently about biomedical science and its challenges. He felt that, to know and do science is not work-it is a privilege, and one is lucky to be able to do it. Sometimes it is hard to remember that lesson, given the difficulties science dishes out. Doing biomedical science truly is a privilege.

Kornberg was a gifted, creative, and brilliant scientist.

He stated, "What makes science unique is the discipline rather than the practitioner. Verifiability and incremental progress distinguish science from all other art forms."

In his reflections on his life in science, Kornberg focused on the clinical investigator-"I can think of nothing more destructive of the productivity of the clinical investigator than a failure to focus sharply on a single problem over a long space of time. The chief cause of this failure to advance knowledge is not a lack of effort, or motivation or opportunity. It is not a lack of creativity, or intelligence, or training. The clinical investigator fails when he lets problems choose and dominate him, rather than the reverse. The investigator must ask a small and modest question, focus on it in laser-beam fashion, and then maintain the focus until the beam burns through."

Recently, with concern that America's universities are at risk, the US Congress asked the National Academies of Science to assess the competitive position of America's research universities. Just over a year ago, the National Research Council of the US National Academies of Science released its study "Research Universities and the Future of America" (5).

It begins, "America is driven by innovation-advances in ideas, products and processes that create new industries and jobs, contribute to our nation's health and security and support a high standard of living. In the past half-century, innovation itself has been increasingly driven by educated people and the knowledge they produce. Our nation's primary source of both new knowledge and graduates with advanced skills continues to be our research universities."

"American research universities are widely recognized as the best in the world, admired for their education and research. They have the potential to drive innovation in areas important to America's future including health and medicine."

Among today's critical challenges, they note is that "young faculty have insufficient opportunities to launch academic careers and research programs." 


\section{Special Article}

\section{Schwartz}

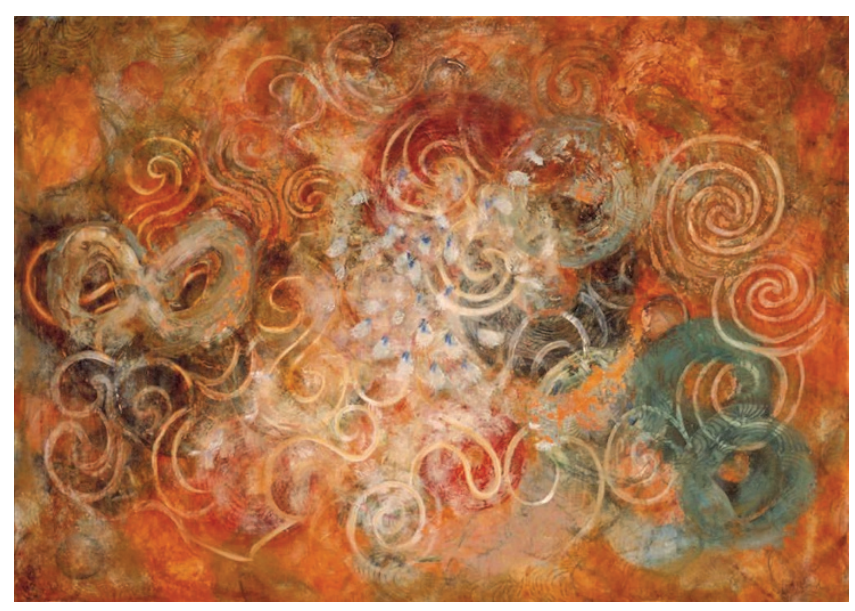

Figure 3. Aegean Suite, by Judy Child. Reprinted with permission from Judy Child.

Last week, in PNAS Early Edition, Bruce Alberts, Marc Kirshner, Shirley Tilghman, and Harold Varmus addressed several of the issues which discourage many of today's young trainees (6). Among their suggestions intended to stimulate debate are: bringing the biomedical enterprise into sustainable equilibrium and an increase in support for the best science through federal grants.

However this debate evolves, it is our research universities which educate the next generation of question-askers, those who will look differently at today's problems and develop innovative solutions, and those who will confront tomorrow's problems. We must provide as fertile a soil as possible for their growth and development. The possibilities are endless.

Let me conclude with a quote from Henry Rosovsky, former Dean of the Faculty of Arts and Sciences at Harvard and author of The University: An Owner's Manual "In thinking about what draws faculty to research, of uppermost importance comes the love of learning. That may sound trite, sentimental, and self-serving, but nevertheless it is true. Research is an expression of faith in the possibility of progress. The drive that leads scholars to study a topic has to include the belief that new things can be discovered, that newer can be better, and that greater depth of understanding is achievable. Research, especially academic research, is a form of optimism about the human condition" (7).

We must extoll that optimism about the human condition. The challenges are great, our Universities are strong, and our human talent is abundant. The economic climate is challenging; the political climate is challenging; the climate is challenging. Yet, the foundations of biomedical research are secure. Pediatrics needs you. Biomedicine needs you. Today's and tomorrow's children depend on you (Figure 3).

\section{STATEMENT OF FINANCIAL SUPPORT}

A.L.S. is the Harriet B. Spoehrer Professor of Pediatrics.

\section{REFERENCES}

1. Cole JR. The Great American University, Its Rise To Preeminence, Its Indispensable National Role, Why It Must Be Protected. USA: Public Affairs, 2009.

2. Bush V. Science - The Endless Frontier. A Report to the President. Washington: United States Government Printing Office, 1945.

3. Kornberg A. For the Love of Enzymes: The Odyssey of a Biochemist. Harvard University Press, Cambridge, MA, USA, 1989.

4. Kornberg A. Latent liver disease in persons recovered from catarrhal jaundice and in otherwise normal medical students as revealed by the bilirubin excretion test. J Clin Invest 1942;21:299-308.

5. Committee on Research Universities; Board on Higher Education and Workforce (BHEW); Policy and Global Affairs (PGA); National Research Council. Research Universities and the Future of America: Ten Breakthrough Actions Vital to Our Nation's Prosperity and Security. The National Academies Press, Washington, DC, 2012.

6. Alberts B, Kirschner MW, Tilghman S, Varmus H. Rescuing US biomedical research from its systemic flaws. Proc Natl Acad Sci USA 2014;111:5773-7.

7. Rosovsky H. The University: An Owner's Manual. USA: Haddon Craftsmen, 1990. 